\title{
Comparative Study of Control Strategies for Hybrid GSHP System in the Cooling Dominated
}

\section{Climate}

Shaojie Wang ${ }^{\text {a,* }}$

${ }^{a}$ ClimateMaster, 7300 SW $44^{\text {th }}$ Street, Oklahoma City, OK 73179

Xiaobing Liu $^{b}$

${ }^{b}$ Oak Ridge National Lab

Steve Gates ${ }^{c}$

${ }^{c}$ Jeff Hirsch \& Associates

*Corresponding author. Tel.: +1 9722070380.

E-mail address: wsjsxn@gmail.com (S. Wang). 


\begin{abstract}
The ground source heat pump (GSHP) system is one of the most energy efficient HVAC technologies in the current market. However, the heat imbalance may degrade the ability of the ground loop heat exchanger (GLHX) to absorb or reject heat. The hybrid GSHP system, which combines a geothermal well field with a supplemental boiler or cooling tower, can balance the loads imposed on the ground loop heat exchangers to minimize its size while retaining superior energy efficiency. This paper presents a recent simulation-based study with an intention to compare multiple common control strategies used in hybrid GSHP systems, including fixed setpoint, outside air reset, load reset, and wetbulb reset. A small office in Oklahoma City conditioned by a hybrid GSHP system was simulated with the latest version of eQUEST 3.7. The simulation results reveal that the hybrid GSHP system has the excellent capability to meet the cooling and heating setpoints during the occupied hours, balance thermal loads on the ground loop, as well as improve the thermal comfort of the occupants with the reduced size well field.
\end{abstract}

Keywords: hybrid GSHP, heat rejection, entering fluid temperature, control strategy

\title{
1. Introduction
}

As addressed in Buildings Energy Data Book [2], the buildings sector consumes about $40 \%$ of US primary energy including $74 \%$ of electricity consumption, $56 \%$ of natural gas consumption, and significant oil consumption in the Northeastern in 2010. Over the long term, buildings are expected to continue to be a significant component of increasing energy demand and a major source of carbon 
emissions, driven in large part by the continuing trends of urbanization, population and GDP growth, as well as the longevity of building stocks. The increasing importance of building energy efficiency generally, as well as EERE's programmatic focus on net zero energy homes and net zero energy commercial buildings brings tremendous challenges and opportunities to the Heating, Ventilation, AirConditioning, and Refrigeration (HVAC\&R) industry. Many new, or relatively new, HVAC\&R technologies [3] are promoted with emphasis on their superior energy efficiency. Among these, the ground source heat pump is one of the most energy efficient HVAC technologies in the current market.

As shown in Fig.1, the GSHP system rejects the heat to the ground (in the cooling mode) or extracts the heat from the ground (in the heating mode). It takes the advantages of the moderate ground temperatures to increase the efficiency and reduce the operating cost of the HVAC system. It usually comprises of multiple water-to-air heat pump indoor units, which are parallelly connected with the GLHX through a common two-pipe water loop. The GLHX consists of multiple boreholes connected in parallel. Depending on the operation mode of the GSHP system, the fluid is circulated through the boreholes to either reject the heat to the ground or absorb the heat from the ground before returning to the water-toair heat pump indoor units. Since each of the water-to-air heat pump indoor units can run in either cooling or heating mode independently, the GSHP system can provide simultaneous cooling and heating for different zones of the building. As of 2004, Lund et al. [4] reported that over a million GSHP units were installed worldwide to provide $100 \mathrm{MWt}$ of thermal capacity, with an annual growth rate of $10 \%$ [5].

Fig. 1 Schematic of GSHP system 
However, the space cooling and heating loads in the cooling dominated climate such as Oklahoma City are not balanced on an annual basis. This imbalance may degrade the ability of the GLHX to absorb or provide heat. This imbalance may be minimized via the use of a supplemental boiler and/or cooling tower. The supplemental device is usually placed in series with the geothermal heat exchanger, and the control is configured to maximize usage of the geothermal capacity, with the supplemental equipment making up the remainder. The combination of a geothermal well field with a supplemental boiler or cooling tower is termed a "hybrid" GSHP system as presented in Fig. 2.

Fig. 2 Schematic of Hybrid GSHP system

ASHRAE [6] published an engineer manual on how to size the capacity of the cooling tower. Instead of using the building peak loads, the capacity of the cooling tower is determined based on the difference between the monthly average building cooling and heating loads. The ground loop is sized to meet the building heating loads, while the cooling load in excess of the heating load is met through supplemental heat rejection.

Kavanaugh and Rafferty [7] discussed hybrid ground source heat pump systems within the framework of ground loop heat exchanger design alternatives. The sizing of the cooling tower is based on peak block load at the design condition. The nominal capacity is calculated based on the difference between the ground-loop heat exchanger lengths required for cooling and heating.

Kavanaugh [8] recommended calculating the operation hours of the cooling tower based on the cooling setpoint of the ground loop. This revised method can reduce the thermal load aggregation on the ground 
loop and improve the performance of heat pump unit. The author concludes that the economic value of hybrid systems is most apparent in warm and hot climates where cooling loads are the highest. Although hybrid systems with heat recovery options are deemed somewhat attractive for regions of moderate climate, no economic value could be justified for cold climates even with heat recovery.

Yavutzurk and Spitler [9] conducted a comparative study investigating several control strategies for Hybrid GSHP systems. The strategies investigated include full sized GLHX, undersized GLHX with no supplementary heat rejecter, fixed set point control (heat pump entering or exiting fluid temperatures), differential temperature control (the difference between heat pump entering or exiting fluid temperatures and the ambient wet-bulb temperature), and operation of the supplemental rejecter to remove heat from the GLHX field during nighttime hours. The simulate results indicate that the hybrid GSHP system is more cost effective than the conventional GSHP system for 20 year operation period. The differential temperature control is the most beneficial choice as compared with other control strategies.

eQUEST is a widely used, time-proven whole building energy performance design tool. Its wizards, dynamic defaults, interactive graphics, parametric analysis, and rapid execution make eQUEST uniquely able to conduct whole-building performance simulation analysis throughout the entire design process, from the earliest conceptual stages to the final stages of design. While powerful, eQUEST development team still continuously makes improvements and adds new features. Three new enhancements recently have been implemented into eQUEST 3.7 to expand its modeling capacity. These enhancements includes: (1) Simulation of ground coupled water-to-water heat pump systems; (2) Improved multi-year simulations for conventional and hybrid GSHP systems; (3) Models of various hybrid GSHP system configurations. Therefore, eQUEST 3.7 was chosen for this comparative study. 


\section{Description of simulated building}

As shown in Fig. 3, a 2-story small office was selected for this comparison study. Each floor of the office has a square footprint and total conditioned space of $1161 \mathrm{~m}^{2}$, which has four thermal zones in the perimeter and one core zone in the interior. The floor to floor height is $3.66 \mathrm{~m}$ with $0.91 \mathrm{~m}$ high return plenum.

Fig. 3 3D view and floor plan of the simulated small office building

The small office building was assumed to be located in Oklahoma City, OK which lies in Warm Humid Climate zone 3A as described in the ASHRAE standard 90.1-2010. The exterior wall has the 2 in. $(5.1 \mathrm{~cm})$ by 6 in. $(15.2 \mathrm{~cm})$ metal studs framing at 24 in. $(61.0 \mathrm{~cm})$ on center with cavities filled with R-18 batt insulation. The exterior insulation was $3 / 4$ in. $(1.9 \mathrm{~cm})$ fiber board sheathing with the plywood finishing. The roof was constructed by using the metal frame at 24 in. spacing with 3 in. $(7.6 \mathrm{~cm})$ polyurethane (R-18) exterior insulation. The slab was built with 6 in. concrete and interior vinyl tile. Two types of the double pane glazing were installed on the building. The single clear/tint glazing was selected for the exterior door. Table 1 lists the construction details of the small office building. The corresponding internal loads are shown in Table 2 including lighting power density, equipment load and occupant density.

Table 1 Construction of the small office building

Table 2 Internal loads of the small office building 
The office operated from 8 am to $5 \mathrm{pm}$ (Monday to Friday) and was closed on Saturday, Sunday and holiday. The HVAC system ran between 7 am and $6 \mathrm{pm}$. In the cooling mode, the thermostat setpoints were $24^{\circ} \mathrm{C}$ when occupied and $28^{\circ} \mathrm{C}$ when unoccupied. In the heating mode, $21^{\circ} \mathrm{C}$ was selected as occupied room temperature and $18^{\circ} \mathrm{C}$ was used in the unoccupied hours. The indoor fan was assumed to run intermittently with the constant air flow rate during the occupied hours and stay off when unoccupied. The fan efficiency and motor efficiency were 0.62 and 0.77 with 249 Pa pressure rise. Fig.4 shows the daily building occupancy, lighting and equipment schedules.

Fig. 4 Building occupancy, lighting, and equipment schedules 


\section{Hybrid GSHP system model description}

As a key part of HGSHP system, the GLHX was used as a heat source and sink to cool or heat the condenser water. The entering fluid temperature (EFT) to the heat pump from the loop is used to determine the size of the well field. The sizing criterion is that the min EFT is above $7.2^{\circ} \mathrm{C}$ and the max EFT is below $35^{\circ} \mathrm{C}$ during the period of 30 year operation. It can limit the degradation of the performance of the heat pump in the heating and cooling seasons. The GLHX was constructed with 32 ( $4 \times 8$ array) boreholes placed in a rectangular configuration. The borehole depth is $76 \mathrm{~m}$ with the radius of $0.08 \mathrm{~m}$. The U-tube spacing and leg separation are $6 \mathrm{~m}$ and $0.1 \mathrm{~m}$. The pipe thermal conductivity is $0.4 \mathrm{~W} / \mathrm{m} . \mathrm{K}$ with the inside and outside diameters of $0.022 \mathrm{~m}$ and $0.027 \mathrm{~m}$. The ground thermal conductivity and diffusivity are $2.9 \mathrm{~W} / \mathrm{m} . \mathrm{K}$ and $1.11 \times 10^{-6} \mathrm{~m}^{2} / \mathrm{s}$. The undisturbed ground temperature is $18^{\circ} \mathrm{C}$.

The fluid cooler is attached to the same water loop with a ground loop heat exchanger. It is in series with the well field, and downstream of the well field. If the outlet loop temperature is within the circulation loop's cooling/heating setpoint, then the loop temperature floats with the well temperature without running the fluid cooler. If the temperature exceeds the loop's cooling setpoint, then the fluid cooler will operate to maintain the loop temperature at setpoint. The downstream split ratio determines the design heating or cooling load to be picked up by the fluid cooler. For the fluid cooler, the sizing method is to balance the annual heat rejection with heat extraction and reduce the load aggregation on the ground loop. Because the building is highly cooling dominated, the downstream split ratio is 0.8 , which means the fluid cooler is designated to satisfy $80 \%$ of peak cooling load. The fluid cooler is always assumed to be bypassed when inactive. A variable speed fan modulates the air flow to maintain the tower setpoint. The fluid cooler spray pump can run as "STAY-ON". "Stay-on" enables the fluid cooler to have two 
stages of cooling. On the first stage of cooling, the spray pump operates whenever a heat-rejection load exists. If the load can be met using the spray pump and natural convection, then the fan will stay off. Otherwise, the fan will cycle on as required, and when cycled off, the pump will remain on.

Each zone of the small office is served with one packaged water-to-air heat pump unit and controlled independently. The indoor fans run under intermittent mode. The intermittent mode enables the indoor fan to only operate for that fraction of the hour required for space heating or cooling. All the heat pump units are connected to a close-loop vertical ground loop heat exchanger through a common 2-pipe loop.

The central pump station has the variable speed pump. According to their zone thermostats, individual heat pump units extracted heat from or rejected heat to a common water loop. The water loop connected the heat pump units with the GLHX. The water pump attached to the water loop and circulated the water between the GLHX, fluid cooler, and the condenser. It ran intermittently with the rated pump head of $31.9 \mathrm{ft}$ and the motor efficiency of 0.885 . The water flow rate was $16.5 \mathrm{~L} / \mathrm{s}$ which was autosized by eQUEST 3.7.

\section{Loop temperature control strategy}

The set-point temperature is the entering fluid temperature to the heat pump from the loop. The heating and cooling modes have separate set-points. The set-points normally are fixed, but may be varied by load reset, outdoor temperature reset and wetbulb reset.

The GLHX is preferentially loaded over the fluid cooler. However, if the GLHX is counterproductive (i.e., warming the water when heat pumps are in cooling mode), and a fluid cooler is also enabled, then the GLHX will be bypassed (to save pump energy) and the fluid cooler used exclusively. 
The fluid cooler will be enabled when the EFT from the GLHX is higher than the cooling setpoint. When enabled, the fluid cooler will modulate a variable-speed cycling fan to maintain the cooling temperature set-point. When the fluid cooler is disabled, the flow will bypass the fluid cooler.

\section{Description of simulation scenarios}

The multiple control strategies [10] including fixed setpoint, outside air reset, load reset, and wetbulb reset were adopted to optimize the performance of the hybrid GSHP system in term of annual HVAC energy consumptions and unmet cooling/heating hours. The fixed temperature control specifies the EFT to the heat pumps at a fixed value. The OA-RESET specifies that the EFT to the heat pumps is reset on outdoor air according to the COOL-RESET-SCH. LOAD-RESET specifies that the EFT to the heat pumps is reset so that the valve of the worst-case coil is fully open. LOAD-RESET is applicable to the heat-rejection side of the water loop. It does not apply, however, to the heating setpoint of the water loop. The fluid cooler temperature floats with the load and wet-bulb temperature. This mode maximizes the efficiency of the primary equipment and minimizes the loop's thermal losses (but at the expense of pumping energy in a variable-flow loop). WETBULB-RESET specifies that the EFT to the heat pumps is reset according to the outdoor wetbulb temperature, plus an offset. The offset may be either fixed, or may vary with the wetbulb.

\section{Conventional GSHHP system}

The conventional GSHP system was simulated as a base case to compare with the hybrid GSHP system. The simulation for this case only includes the GLHX, the circulation pump, and the heat pump indoor units. The GLHX was designated without the use of any supplementary heat rejection equipment. The GSHP system fully depends on the GLHX to meet the building heat and cooling loads. The sizing method of the GLHX uses the same max and min EFTs as addressed above with a 30-year operation period. Therefore, the well field is comprised of 72 boreholes in an $8 \times 9$ rectangular configuration. 
Other related design parameters of the GLHX are identical to those specified for the hybrid GSHP system.

\section{Fixed Cooling Setpoint}

Table 3 lists the simulation scenarios with fixed cooling setpoint control. The fixed cooling setpoints are $23.9^{\circ} \mathrm{C}, 26.7^{\circ} \mathrm{C}$, and $29.4^{\circ} \mathrm{C}$ while the fixed heating setpoint is $-0.6^{\circ} \mathrm{C}$.

Table 3 Simulation scenarios with fixed cooling setpoint control

\section{OA-RESET}

Three OA-Reset temperature schedules are listed in Table 4. OA-Reset schedule defines the relationship between the cooling setpoint and the outdoor drybulb temperature for each hour of the run period. RESET-SCHEDULE specifies four required keywords including Outdoor-Low, Outdoor-Hi, Cooling$\mathrm{Hi}$, and Cooling-Low. The cooling setpoint "Cooling-Low" keeps at $15.6^{\circ} \mathrm{C}$ while the outdoor drybulb low temperature "Outdoor-Low" is $12.8^{\circ} \mathrm{C}$. Corresponding to Outdoor-Hi at $29.4^{\circ} \mathrm{C}$, the cooling setpoint "Cooling-Hi" increases from $23.9^{\circ} \mathrm{C}$ up to $29.4^{\circ} \mathrm{C}$ with 2.8 degree increment. Fig. 5 shows the curves of cooling setpoint at various outdoor drybulb temperatures.

Table 4 Simulation scenarios with OA-Reset cooling setpoint control

Fig. 5 Cooling setpoint at various outdoor drybulb temperatures

\section{Wetbulb-RESET}

Three Wetbulb-Reset temperature schedules were listed in Table 6 . The hourly cooling setpoint $T_{1}$ is calculated in the following equation. As shown in Table 5, the differential between the cooling setpoint 
and outdoor wetbulb temperature are $0.6,2.8$, and $5.6^{\circ} \mathrm{C}$.

$\mathrm{T}_{1}=\mathrm{T}_{2}+\Delta \mathrm{T}$

Where

$\mathrm{T}_{2}$ : hourly outdoor wetbulb temperature

$\Delta \mathrm{T}$ : differential between the hourly cooling setpoint and hourly outdoor wetbulb temperature

Table 5 Simulation scenarios with wet-bulb reset cooling control

\section{Load-RESET}

Using LOAD-RESET, the program does not calculate a loop setpoint temperature. Instead, the fluid cooler fan speed is reset directly on the tower load. The tower leaving temperature floats with the wetbulb temperature, load, and resulting fan speed. The MAX-RESET-T of the circulation loop specifies the upper limit of the floating tower temperature, and MIN-RESET-T specifies the lower limit. If either of these limits is exceeded, then the fan will modulate to not exceed the limit. When a variablespeed fan is used, this is the minimum fraction of nominal fan speed at which the fan can operate. If the load is such that the component will overcool the fluid at this minimum speed, then the fan will cycle between off and minimum speed. For current study, the minimum fan speed is 0.4 while minimum reset part load ratio is 0.3 . The maximum reset speed is 0.8 . The correlation of the fan speed and part load ratios is depicted in Fig. 6.

Fig. 6 Correlation of fan speed and part load ratio

Three Load-Reset temperature schedules are listed in Table 6. The MAX-RESET-T and the MINRESET-T are the upper and lower limits on the supply temperature. The actual setpoint will be reset, 
based on coil demand, between the MAX-RESET-T and the MIN-RESET-T. The MAX-RESET-T is between $23.9^{\circ} \mathrm{C}$ and $29.4^{\circ} \mathrm{C}$ while MIN-RESET-T is $15.6^{\circ} \mathrm{C}$.

Table 6 Simulation scenarios with load-Reset cooling control

\section{Result and Discussion}

The simulation results are analyzed in this section including annual HVAC electric consumption, heat rejections, average entering fluid temperatures to heat pump and unmet hours.

\subsection{Conventional GSHP}

For the base case, the GLHX was sized without any supplemental heat rejection equipment. Then, the well field is more than twice as large as what the hybrid GSHP needs by applying the same sizing criterion. As shown in Table 7, the conventional GSHP system consumes the lowest HVAC electric consumption in year 1 as compared with the hybrid GSHP system. The peak heating and cooling loads on the ground loop are $225 \mathrm{kw}$ and $392 \mathrm{kw}$. Annually, the heat rejection to the ground is $233 \mathrm{MHW}$ and $243 \mathrm{MHW}$ in year 1 and year 30. The GSHP system only absorbs $6 \mathrm{MWH}$ heat from the ground in the

heating mode. So, the max and min EFTs are $33.8^{\circ} \mathrm{C}$ and $23.6^{\circ} \mathrm{C}$ in year 30 . The average EFTs are 19.7 ${ }^{\circ} \mathrm{C}$ in year 1 and $27.6^{\circ} \mathrm{C}$ in year 30, respectively. As a result of the heat imbalance on the ground loop, the average EFT rises $7.9^{\circ} \mathrm{C}$ with a 30 year operation.

Table 7 HVAC electric consumptions (kWh) in Year 1 (conventional GSHP system)

\subsection{Annual HVAC Electric Consumption}

The HVAV electric consumption is the most important factor to compare the different control strategies analyzed in this study. Besides the annual HVAC electric consumption, six categories of energy end 
uses are also listed for each control strategies including space cool, tower fan, spray pump, space heat, vent. fans, and loop pump.

\subsubsection{Fixed Cooling Setpoint}

As shown in Table 7, Fixed-2 and Fixed-3 reduce the annual HVAC electric consumption by $12.7 \%$ and $12.3 \%$ as compared with Fixed-1 due to the higher cooling setpoint. The major electric savings come from the reduction of the electric usage of the fluid cooler fan, which are $5616 \mathrm{kWh}$ and $6130 \mathrm{kWh}$. In addition, the energy end uses for spray pump also drop from $2274 \mathrm{kWh}$ to $1655 \mathrm{kWh}$ and $1103 \mathrm{kWh}$, as well as the loop pump with the energy savings of $1345 \mathrm{kWh}$ and $1429 \mathrm{kWh}$. The space cooling end use gradually increases from $29097 \mathrm{kWh}$ to $30463 \mathrm{kWh}$ and $31703 \mathrm{kWh}$ because the higher EFTs from the ground loop degrades the performance of the heat pump in the cooling mode. The energy end uses for space heat and indoor fan don't change significantly among three case studies. However, an interesting phenomenon observed here is that Fixed-3 uses more energy than Fixed-2. This result indicates that the higher cooling setpoint cannot guarantee the energy savings of the HVAC system. When the energy end use of the fluid cooler is only a small portion (5.2\%) of the annual HVAC energy consumption for Fixed-2, the benefit to further lower the operation duration/frequency of the fluid cooler associated with the higher cooling setpoint is very limited as addressed in Table 7. At the meantime, the penalty of increasing the energy end use for the heat pump offsets the energy savings in Fixed-3.

Table 8 HVAC electric consumptions (kWh) in Year 1 (Fixed Cooling Setpoint)

Fig.7 shows the hourly loop control setpoints and EFTs to the heat pumps. As the cooling control setpoint increases from $23.9^{\circ} \mathrm{C}$ to $29.4^{\circ} \mathrm{C}$, the EFT to the heat pumps increases accordingly. For Fixed-1, 
there are some hours when the EFTs to the heat pump exceed $23.9^{\circ} \mathrm{C}$. Then, the hours decrease with the higher cooling setpoints accordingly.

Fig. 7 Hourly Cooling control setpoint and EFT to the heat pump for Fixed-1, Fixed-2, and Fixed-3

\subsubsection{OA-Reset Cooling Setpoint}

As shown in Table 8, the HVAC electric consumptions reduce from $55082 \mathrm{kWh}$ to $44198 \mathrm{kWh}$ and $43740 \mathrm{kWh}$ as the supply leaving temperature at the outdoor drybulb high increases every 2.8 degree $\mathrm{C}$ The energy end use for space cooling keeps increasing due to the higher temperature of the supply water from the circulation loop into the condenser. Compared with OA-1, the energy end uses for the fluid cooler fan drop $86.4 \%$ for OA-2 and $98.0 \%$ for OA-3, respectively. Similarly, the spray pump and loop pump totally saves $2795 \mathrm{kWh}$ and $3423 \mathrm{kWh}$.

Table 8 HVAC Electric consumptions $(\mathrm{kWh})$ in year 1 (OA-RESET)

Unlike fixed cooling setpoint control, the cooling setpoint for OA-Reset has a linear relationship with the outdoor drybulb temperature. Fig. 8 shows that the EFT to the heat pumps varies between the upper $\left(23.9^{\circ} \mathrm{C}, 26.7^{\circ} \mathrm{C}\right.$, and $\left.29.4^{\circ} \mathrm{C}\right)$ and lower $\left(15.6^{\circ} \mathrm{C}\right)$ limits of $\mathrm{OA}$ reset schedules. The hours exceeding the upper limits are gradually reduced as these upper limits increase.

Fig. 8 Hourly cooling control setpoint and EFT to the heat pump for OA-1, OA-2, and OA-3

\subsubsection{Wetbulb Reset Cooling Setpoint}


In order to investigate the impact of WETBULB-RESET DT on the HVAC electric consumption, cases WB-1 to WB-3 were simulated with WETBULB-RESET DT at $0.6^{\circ} \mathrm{C}, 2.8^{\circ} \mathrm{C}$, and $5.6^{\circ} \mathrm{C}$. Table 9 presents that total HVAC electric consumption decreases from $77955 \mathrm{kWh}$ to $45518 \mathrm{kWh}$ when WETBULB-RESET DT increases from $0.6^{\circ} \mathrm{C}$ up to $2.8^{\circ} \mathrm{C}$. As addressed before, the electric end uses for fan and space heat are quite stable for three case scenarios. Further increasing DT to $5.6^{\circ} \mathrm{C}$ only reduces the HVAC electric consumption by $1957 \mathrm{kWh}$. Fig.9 presents that the EFT to the heat pumps is quite stable when the outdoor wetbulb temperature is quite below the ground temperature. This occurs in the heating season when the building occasionally requires cooling. In the cooling season, the EFT continuously changes with the outdoor wetbulb temperature.

Table 9 HVAC electric eonsumptions (kWh) in Year 1 (WB-RESET)

Fig. 9 Hourly cooling control setpoint and EFT to the heat pump for WB-1, WB-2, and WB-3

\subsubsection{Load Reset Cooling Setpoint}

Load-Reset actually shows quickly similar trend as OA-Reset as presented in Tables 10. The higher MAX-RESET-T can drop the energy end use for fluid cooler including fan and spray pump but increase the energy end use for space cooling. Overall, the total HVAC energy can be saved with this cooling control strategy. Fig. 10 shows that the fan runs less frequently when MAX-RESET-T increases. The EFT to heat pumps increases accordingly.

Table 10 HVAC Electric Consumptions (kWh) in Year 1 (LD-RESET) 
Fig. 10Hourly fan speed and EFT to the heat pump for LD-1, LD-2, and LD-3

\subsection{Heat rejection and EFT rise}

Table 8 summarizes fluid cooler rejection loads, GLHX heating/cooling loads, and max/min entering fluid temperatures to the heat pump for various control strategies in year 1 and year 30 . On an annual basis, the heat rejection to the ground is much higher than the heat extraction from the ground. So, even with the supplementary heat rejecter like the fluid cooler, the heat still is built up in the ground. The increment of the max and min EFTs proves the load aggregation in the ground during the 30 year operation. In year 30, the GLHX rejects less heat than the amount of the heat rejected in year 1 due to the temperature rise in the ground. Conversely, the fluid cooler runs somewhat longer to main the cooling setpoint by rejecting more heat to the air. Basically, the heat rejection load just shifts from the GLHX to the fluid cooler. A comparison among twelve control strategies shows that due to the higher cooling setpoint, a general increase in the heat rejection to the ground via the GLHX is observed in year 1 and year 30. Accordingly, the fluid cooler is activated less with the reduced heat rejection to the air.

Table 11 Heat rejections by GLHX/fluid cooler and EFT rise in Year 1 and Year 30

\subsection{Average entering fluid temperature to heat pump}

The average entering fluid temperature is key parameter that affects the performance of the heat pump. Table 11 lists average EFTs in year 1 and year 30, and average EFT rises. The average EFT in year 1 is in the range of $17.9^{\circ} \mathrm{C}$ and $23.6^{\circ} \mathrm{C}$. In year 30, the average EFT to heat pumps varies between $18.2^{\circ} \mathrm{C}$ and $28.3^{\circ} \mathrm{C}$. Because the heat rejection to the ground is much larger than the heat extraction from the ground even with the supplemental fluid cooler, the ground temperature gradually increases during the 
course of the 30 year operation. For the current study, the average EFT rise from $0.2{ }^{\circ} \mathrm{C}$ up to $4.2^{\circ} \mathrm{C}$, respectively.

Table 12 Average entering fluid temperatures in the cooling mode

Based on the simulation result, the loop cooling control strategies can be divided into four categories as follows. In category 1, Fixed-2 and Fixed-3 have the lowest HVAC electric consumption but highest EFT rise. OA-2, OA-3, WB-2, and WB-3 have relative high HVAC electric consumption as compared with Fixed-2 and Fixed-3. However, they also have the lowest EFT rise among four categories. Category 3 including Fixed-1 and LD-3 show higher HVAC electric consumption and EFT rise as compared with second category. The last category includes LD-1, LD-2, OA-1, and WB-1, which have the highest HVAC electric consumption but the lowest EFT rise. So, OA-2, OA-3, WB-2, and WB-3 can successfully balances the thermal load on the ground loop. While the reduced size well field is combined with the supplemental heat rejection device, the heat pump units still can run at the relative high efficiency.

Loop cooling control strategy:

1. Fixed-2 and Fixed-3

2. OA-2,OA-3, WB-2, and WB-3

3. Fixed-1 and LD-3

4. LD-1, LD-2, OA-1, and WB-1

\subsection{Unmet hour}

Besides the annual HVAC electric consumptions and max/min EFTs, the unmet hours also can be used 
to evaluate the performance of the hybrid GSHP system. The thermostat throttling range is $0.28^{\circ} \mathrm{C}$. If the zone temperature is away from the cooling/heating setpoint by more than this value, the cooling/heating unmet hours will increment as appropriate. As required by LEED, the unmet hours are within 300 hours. For this study, the unmet hours are between 10 and 11 hours. This indicates that the room temperature was well controlled by the hybrid GSHP system.

Table 13 Unmet hours of any zone above cooling/heating throttling range

\section{Conclusion}

The newly released eQUEST 3.7 was selected to simulate a ground loop heat exchanger together with supplemental heat rejection device to reduce the size of the well field from $72(8 \times 9$ array) boreholes to 32 ( $4 \times 8$ array) boreholes. The multiple control strategies including fixed setpoint, outside air reset, load reset, and wetbulb reset were adopted to optimize the performance of the hybrid GSHP system. For the first year of operation, the conventional GSHP system uses less electric energy than the hybrid GSHP system by taking the advantage of much larger well field ( $8 \times 9$ array). However, due to the heat imbalance on the ground loop, the EFT rises much faster than any case scenarios simulated for the hybrid GSHP system.

For the hybrid GSHP system, Fixed-2 has the lowest HVAC energy consumption in year 1. It takes advantage of moderate ground temperature to reject the heat load to the ground and balances the energy end uses between heat pump and cooling tower. However, it has the second highest average EFT rise in year 30 among all 12 case scenarios. 
In general, the control strategies that reject more heat through the GLHX give more benefit than those that reject less heat through the GLHX. However, the simulation results also indicate that the higher cooling setpoint cannot guarantee the energy savings of the HVAC system. When the energy end use of the fluid cooler is only a small portion (5.2\%) of the annual HVAC energy consumption, the benefit to further lower the operation duration/frequency of the fluid cooler associated with the higher cooling setpoint is very limited. At the meantime, the penalty of increasing the energy end use for the heat pump can offset the energy savings from the fluid cooler.

For $67 \%$ of case studies, the average EFT to heat pumps is quite constable as the rise of EFT is less than $0.6^{\circ} \mathrm{C}$ during the 30 year operation period. So, the indoor unit can run at the relative high efficiency during the cooling season. From the heating side, the hybrid GSHP can benefit from the increasing of minimum EFTs to the heat pumps. As indicated by the rise of average EFTs, the thermal load is well balanced on the ground loop in the cooling dominated climate zone such as Oklahoma City with the loop cooling control strategies such as OA-2, OA-3, WB-2, and WB-3. The unmet hours are around 10 hours during the course of the first year operation. With properly loop cooling control strategies, the hybrid GSHP system shows the excellent capability to meet the cooling and heating setpoints during the occupied hours, balance thermal loads on the ground loop, as well as improve the thermal comfort of the occupants with the reduced size of the well field.

\section{Acknowledgement}

This work is based upon work supported by the U. S. Department of Energy under Award No. DEEE002799. 


\section{Nomenclature}

Outdoor-Hi: upper limit of outdoor drybulb temperaturre

Outdoor-Low: lower limit of outdoor drybulb temeprature

Cooling-Hi: cooling setpoint corresponding to the upper limit of outdoor drybulb temperaturre

Cooling-Low: cooling setpoint corresponding to the lower limit of outdoor drybulb temeprature

MAX-RESET-T: upper limit of the floating tower temperature

MIN-RESET-T: lower limit of the floating tower temperature

$\mathrm{T}_{1}$ : hourly cooling temperature setpoint

$\mathrm{T}_{2}$ : hourly outdoor wetbulb temperature

$\Delta \mathrm{T}$ : differential between the hourly cooling setpoint and ambient wetbulb

EFT: entering fluid temperature to the heat pump, ${ }^{\circ} \mathrm{F}\left({ }^{\circ} \mathrm{C}\right)$

\section{References}

[1] DOE-2.3 Volume 6: New features, version beta-1a, http://www.doe2.com/equest, 2013

[2] United States Department of Energy, Energy Efficiency and Renewable Energy homepage, http://buildingsdatabook.eren.doe.gov/ChapterIntro6.aspx, March 2012.

[3] W. Goetzler, R. Zogg, J. Young, J. Schmidt, Energy savings potential and research, development, \& demonstration opportunities for residential building heating, ventilation, and air conditioning systems, 2012.

[4] J. Lund, B. Sanner, L. Rybach, R. Curtis, G. Hellström, Geothermal (ground source) heat pumps, a world overview, 2004.

[5] W. Goetzler, R. Zogg, H. Lisle, J. Burgos, Ground source heat pumps: overview of market status, barriers to adoption, and options for overcoming barriers, 2009. 
[6] ASHRAE, Commercial/institutional ground-source heat pumps engineering manual, Atlanta: American Society of Heating, Refrigerating and Air-Conditioning Engineers, Inc., 1995.

[7] S.P. Kavanaugh and K. Rafferty, Ground-source heat pumps: Design of geothermal systems for commercial and institutional buildings, Atlanta: American Society of Heating, Refrigerating and Air-Conditioning Engineers, Inc., 1997.

[8] S.P. Kavanaugh, A design method for hybrid ground source heat pumps, ASHRAE Transactions 104 (2), 1998, pp. 691-698.

[9] C. Yavuzturk and J.D. Spitler, Comparative Study to Investigate Operating and control Strategies for Hybrid Ground Source Heat Pump Systems Using a Short Time-step Simulation Model, ASHRAE Transactions 106(2), 2000, pp.192-209.

[10] DOE-2.3 Volume 2: Dictionary, http://www.doe2.com/equest, 2013 


\section{FIGURE CAPTIONS}

Fig. 1 Schematic of GSHP system

Fig. 2 Schematic of Hybrid GSHP system

Fig. 3 3D view and floor plan of the simulated small office building

Fig. 4 Building occupancy, lighting, and equipment schedules

Fig. 5 Cooling setpoint at various outdoor drybulb temperatures

Fig. 6 Correlation of fan speed and part load ratio

Fig. 7 Hourly Cooling control setpoint and EFT to the heat pump for Fixed-1, Fixed-2, and Fixed-3

Fig. 8 Hourly cooling control setpoint and EFT to the heat pump for OA-1, OA-2, and OA-3

Fig. 9 Hourly cooling control setpoint and EFT to the heat pump for WB-1, WB-2, and WB-3

Fig. 10 Hourly fan speed and EFT to the heat pump for LD-1, LD-2, and LD-3 


\section{TABLE CAPTIONS}

Table 1 Construction of the small office building

Table 2 Internal loads of the small office building

Table 3 Simulation scenarios with fixed cooling setpoint sontrol

Table 4 Simulation scenarios with oa-reset cooling setpoint control

Table 5 Simulation scenarios with load-Reset cooling control

Table 6 Simulation scenarios with wet-bulb reset cooling control

Table 7 HVAC electric consumptions (kWh) in year 1 (conventional GSHP system)

Table 8 HVAC electric consumptions (kWh) in year 1 (Fixed)

Table 9 HVAC electric consumptions (kWh) in year 1 (OA-RESET)

Table 10 HVAC electric consumptions (kWh) in year 1 (WB-RESET)

Table 11 HVAC electric consumptions (kWh) in year 1 (LD-RESET)

Table 12 Heat rejections by GLHX/fluid cooler and EFT rise in year 1 and year 30

Table 13 Average entering fluid temperatures in the cooling mode

Table 14 Unmet hours of any zone above cooling/heating throttling range 
Table 1 Construction of the small office building

\begin{tabular}{|c|c|}
\hline Building Envelope & Construction Detail \\
\hline Exterior wall & 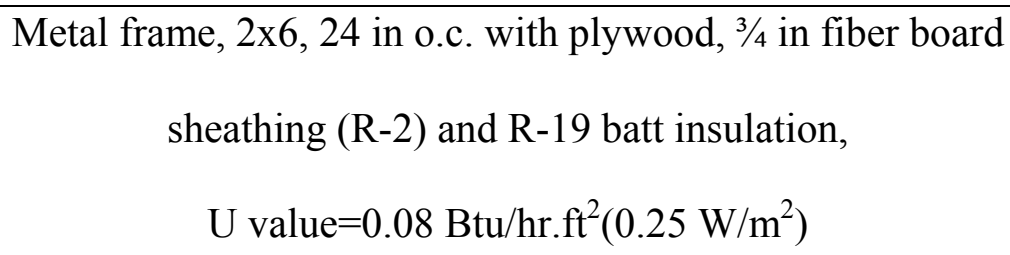 \\
\hline Roof & $\begin{array}{l}\text { Metal frame, } 24 \text { in. o.c. built-up roof with } \mathrm{R}-18 \\
3 \text { in. polyurethane insulation } \\
\mathrm{U} \text { value }=0.042 \mathrm{Btu} / \mathrm{hr}_{\mathrm{ft}}{ }^{2}\left(0.13 \mathrm{~W} / \mathrm{m}^{2}\right)\end{array}$ \\
\hline Floor & Slab-on-grade with 6 in concrete and vinyl tile \\
\hline Windows & $\begin{array}{l}\text { 1) Double pane clear, } 1 / 2 \text { in glass, } 1 / 2 \text { in air gap } \\
U=0.47 \mathrm{Btu} / \mathrm{hr}_{\mathrm{ft}} \mathrm{ft}^{2}\left(1.48 \mathrm{~W} / \mathrm{m}^{2}\right) \\
\text { 2) Double pane clear, } 1 / 2 \text { in glass, } 1 / 4 \text { in air gap } \\
\mathrm{U}=0.54 \mathrm{Btu} / \mathrm{hr} . \mathrm{ft}^{2}\left(1.69 \mathrm{~W} / \mathrm{m}^{2}\right)\end{array}$ \\
\hline Door & $\begin{array}{c}\text { Single clear } / \text { tint } \\
\mathrm{U}=0.98 \mathrm{Btu} /{\mathrm{hr} . \mathrm{ft}^{2}}^{2}\left(3.1 \mathrm{~W} / \mathrm{m}^{2}\right)\end{array}$ \\
\hline
\end{tabular}

Table 2 Internal loads of the small office building

\begin{tabular}{|c|c|}
\hline Internal Load & Unit \\
\hline Light power density & $16.1 \mathrm{w} / \mathrm{m}^{2}$ \\
\hline Equipment load & $10.8 \mathrm{w} / \mathrm{m}^{2}$ \\
\hline Occupant density & 11 people $/ 100 \mathrm{~m}^{2}$ \\
\hline
\end{tabular}


Table 3 Simulation scenarios with fixed cooling setpoint control

\begin{tabular}{|l|l|l|}
\hline \multicolumn{1}{|c|}{ Case No. } & Loop Temp. Heating Setpoint & Loop Temp. Cooling Setpoint \\
\hline $\mathbf{1}$ & $-0.6^{\circ} \mathrm{C}$ & $23.9^{\circ} \mathrm{C}$ \\
\hline $\mathbf{2}$ & $-0.6^{\circ} \mathrm{C}$ & $26.7^{\circ} \mathrm{C}$ \\
\hline $\mathbf{3}$ & $-0.6^{\circ} \mathrm{C}$ & $29.4^{\circ} \mathrm{C}$ \\
\hline
\end{tabular}

Table 4 Simulation scenarios with oa-reset cooling setpoint control

\begin{tabular}{|l|l|l|l|l|}
\hline Case No. & Outdoor-Hi & Outdoor-Low & Cooling-Hi & Cooling-Low \\
\hline OA-1 & $29.4^{\circ} \mathrm{C}$ & $12.8^{\circ} \mathrm{C}$ & $23.9^{\circ} \mathrm{C}$ & $15.6^{\circ} \mathrm{C}$ \\
\hline OA-2 & $29.4^{\circ} \mathrm{C}$ & $12.8^{\circ} \mathrm{C}$ & $26.7^{\circ} \mathrm{C}$ & $15.6^{\circ} \mathrm{C}$ \\
\hline OA-3 & $29.4^{\circ} \mathrm{C}$ & $12.8^{\circ} \mathrm{C}$ & $29.4^{\circ} \mathrm{C}$ & $15.6^{\circ} \mathrm{C}$ \\
\hline
\end{tabular}

Table 5 Simulation scenarios with load-reset cooling control

\begin{tabular}{|l|l|l|}
\hline Case No. & MAX-RESET-T & MIN-RESET-T \\
\hline LD-1 & $23.9^{\circ} \mathrm{C}$ & $15.6^{\circ} \mathrm{C}$ \\
\hline LD-2 & $26.7^{\circ} \mathrm{C}$ & $15.6^{\circ} \mathrm{C}$ \\
\hline LD-3 & $29.4^{\circ} \mathrm{C}$ & $15.6^{\circ} \mathrm{C}$ \\
\hline
\end{tabular}


Table 6 Simulation scenarios with wet-bulb reset cooling control

\begin{tabular}{|l|l|}
\hline Case No. & $\Delta \mathrm{T}$ \\
\hline WB-1 & $0.6^{\circ} \mathrm{C}$ \\
\hline WB-2 & $2.8^{\circ} \mathrm{C}$ \\
\hline WB-3 & $5.6^{\circ} \mathrm{C}$ \\
\hline
\end{tabular}

Table 7 HVAC electric consumptions (kWh) in year 1 (conventional GSHP system)

\begin{tabular}{|c|c|}
\hline Case No. & GSHP \\
\hline Space Cool & 27196 \\
\hline Tower Fan & 0 \\
\hline Spray Pump & 0 \\
\hline Space Heat & 1344 \\
\hline Vent. Fans & 5660 \\
\hline Loop pump & 2187 \\
\hline HVAC Total & 36387 \\
\hline
\end{tabular}


Table 8 HVAC electric consumptions (kWh) in year 1 (Fixed)

\begin{tabular}{|c|c|c|c|}
\hline Case No. & Fixed-1 & Fixed-2 & Fixed-3 \\
\hline Space Cool & 29097 & 30463 & 28 \\
\hline Tower Fan & 6158 & 542 & 1103 \\
\hline Spray Pump & 2274 & 1655 & 1386 \\
\hline Space Heat & 1388 & 1387 & 5906 \\
\hline Vent. Fans & 5764 & 5836 & 2470 \\
\hline Loop Pump & 3899 & 2545 & 42595 \\
\hline HVAC Total & 48579 & 42428 & \\
\hline
\end{tabular}

Table 9 HVAC electric consumptions (kWh) in year 1 (OA-RESET)

\begin{tabular}{|c|c|c|c|}
\hline Case No. & OA-1 & OA-2 & OA-3 \\
\hline Space Cool & 27783 & 29010 & 30370 \\
\hline Fluid Cooler Fan & 10858 & 1479 & 3293 \\
\hline Spray Pump & 4034 & 3841 & 1388 \\
\hline Space Heat & 1390 & 1389 & 5840 \\
\hline Vent. Fans & 5702 & 5766 & 2634 \\
\hline Loop Pump & 5316 & 2713 & 43740 \\
\hline HVAC Total & 55082 & 44198 & \\
\hline
\end{tabular}


Table 10 HVAC electric consumptions (kWh) in year 1 (WB-RESET)

\begin{tabular}{|c|c|c|c|}
\hline Case No. & WB-1 & WB-2 & WB-3 \\
\hline Space Cool & 26936 & 27779 & 29557 \\
\hline Fluid Cooler Fan & 28983 & 3316 & 300 \\
\hline Spray Pump & 4249 & 4199 & 3790 \\
\hline Space Heat & 1396 & 1396 & 1394 \\
\hline Vent. Fans & 5663 & 5707 & 5800 \\
\hline Loop Pump & 10727 & 3122 & 43567 \\
\hline HVAC Total & 77955 & 45518 & \\
\hline
\end{tabular}

Table 11 HVAC electric consumptions (kWh) in year 1 (LD-RESET)

\begin{tabular}{|c|c|c|c|}
\hline Case No. & LD-1 & LD-2 & LD-3 \\
\hline Space Cool & 27070 & 27617 & 28253 \\
\hline Heat Reject. & 9498 & 3631 & 2364 \\
\hline Space Heat & 1391 & 1389 & 1388 \\
\hline Vent. Fans & 5668 & 5693 & 5722 \\
\hline Pumps \& Aux. & 13891 & 11778 & 9273 \\
\hline HVAC Total & 57518 & 50108 & 47001 \\
\hline
\end{tabular}


Table 12 Heat rejections by GLHX/fluid cooler and EFT rise in year 1 and year 30

\begin{tabular}{|c|c|c|c|c|c|c|}
\hline Case No. & Year & $\begin{array}{l}\text { Fluid cooler Heat } \\
\text { Rejection Load } \\
\text { (MWH) }\end{array}$ & $\begin{array}{l}\text { GLHX Cool Load } \\
\text { (MWH) }\end{array}$ & $\begin{array}{c}\text { GLHX Heat Load } \\
\text { (MWH) }\end{array}$ & $\operatorname{Max} \operatorname{EFT}\left({ }^{\circ} \mathrm{C}\right)$ & Min EFT $\left({ }^{\circ} \mathrm{C}\right)$ \\
\hline \multirow[t]{2}{*}{ Fixed-1 } & Year 1 & 63 & 173 & -6 & 29.4 & 8.9 \\
\hline & Year 30 & 137 & 101 & -6 & 30.7 & 15.2 \\
\hline \multirow[t]{2}{*}{ Fixed-2 } & Year 1 & 38 & 199 & -6 & 29.6 & 8.9 \\
\hline & Year 30 & 117 & 122 & -6 & 31.2 & 16.6 \\
\hline \multirow[t]{2}{*}{ Fixed-3 } & Year 1 & 19 & 219 & -6 & 31.6 & 8.9 \\
\hline & Year 30 & 96 & 144 & -6 & 33.0 & 17.9 \\
\hline \multirow[t]{2}{*}{ OA-1 } & Year 1 & 99 & 138 & -6 & 29.3 & 8.9 \\
\hline & Year 30 & 161 & 77 & -6 & 30.2 & 13.5 \\
\hline \multirow[t]{2}{*}{ OA-2 } & Year 1 & 76 & 159 & -6 & 29.5 & 8.9 \\
\hline & Year 30 & 148 & 89 & -6 & 30.6 & 14.3 \\
\hline \multirow[t]{2}{*}{ OA-3 } & Year 1 & 54 & 183 & -6 & 31.4 & 8.9 \\
\hline & Year 30 & 134 & 104 & -6 & 32.4 & 15.3 \\
\hline \multirow[t]{2}{*}{ WB-1 } & Year 1 & 130 & 110 & -6 & 29.2 & 8.8 \\
\hline & Year 30 & 170 & 71 & -6 & 30.1 & 12.9 \\
\hline \multirow[t]{2}{*}{ WB-2 } & Year 1 & 111 & 124 & -6 & 30.4 & 8.8 \\
\hline & Year 30 & 159 & 76 & -6 & 31.3 & 13.3 \\
\hline \multirow[t]{2}{*}{ WB-3 } & Year 1 & 76 & 161 & -6 & 32.7 & 8.8 \\
\hline & Year 30 & 142 & 95 & -6 & 33.7 & 14.6 \\
\hline \multirow[t]{2}{*}{ LD-1 } & Year 1 & 120 & 121 & -6 & 29.2 & 8.9 \\
\hline & Year 30 & 169 & 71 & -6 & 30.1 & 13.1 \\
\hline \multirow[t]{2}{*}{ LD-2 } & Year 1 & 102 & 137 & -6 & 29.3 & 8.9 \\
\hline & Year 30 & 164 & 75 & -6 & 30.2 & 13.5 \\
\hline \multirow[t]{2}{*}{ LD-3 } & Year 1 & 84 & 154 & -6 & 29.6 & 8.9 \\
\hline & Year 30 & 152 & 86 & -6 & 30.7 & 14.3 \\
\hline
\end{tabular}


Table 13 Average entering fluid temperatures in the cooling mode

\begin{tabular}{|c|c|c|c|}
\hline Case No. & $\begin{array}{c}\text { Average EFT }\left({ }^{\circ} \mathrm{C}\right) \text { in } \\
\text { Year 1 }\end{array}$ & $\begin{array}{c}\text { Average EFT }\left({ }^{\circ} \mathrm{C}\right) \text { in } \\
\text { Year 30 }\end{array}$ & $\begin{array}{c}\Delta \mathrm{T}\left({ }^{\circ} \mathrm{C}\right) \text { in } \\
\text { Year 30 }\end{array}$ \\
\hline Fixed-1 & 21.9 & 23.8 & 1.8 \\
\hline Fixed-2 & 23.2 & 26.0 & 2.8 \\
\hline Fixed-3 & 24.1 & 28.3 & 4.2 \\
\hline OA-1 & 19.8 & 20.2 & 0.3 \\
\hline OA-2 & 20.9 & 21.2 & 0.3 \\
\hline OA-3 & 22.1 & 22.6 & 0.3 \\
\hline WB-1 & 17.9 & 18.2 & 0.2 \\
\hline WB-2 & 18.7 & 18.8 & 0.3 \\
\hline WB-3 & 20.6 & 20.9 & 0.2 \\
\hline LD-1 & 18.9 & 19.2 & 0.5 \\
\hline LD-2 & 20.0 & 20.5 & 1.1 \\
\hline LD-3 & 20.9 & 22.1 & \\
\hline & & & \\
\hline & & & \\
\hline
\end{tabular}


Table 14 Unmet hours of any zone above cooling/heating throttling range

\begin{tabular}{|c|l|l|l|}
\hline Case No. & Cooling unmet hour & Heating unmet hour & Total Unmet hour \\
\hline Fixed-1 & 8 & 2 & 10 \\
\hline Fixed-2 & 8 & 2 & 10 \\
\hline Fixed-3 & 9 & 2 & 11 \\
\hline OA-1 & 8 & 2 & 10 \\
\hline OA2 & 8 & 2 & 10 \\
\hline OA-3 & 9 & 2 & 11 \\
\hline WB-1 & 8 & 2 & 10 \\
\hline WB-2 & 8 & 2 & 10 \\
\hline WB-3 & 8 & 2 & 10 \\
\hline LD-1 & 8 & 2 & 10 \\
\hline LD-2 & 8 & 2 & 10 \\
\hline LD-3 & 8 & 2 & 10 \\
\hline & & & \\
\hline
\end{tabular}




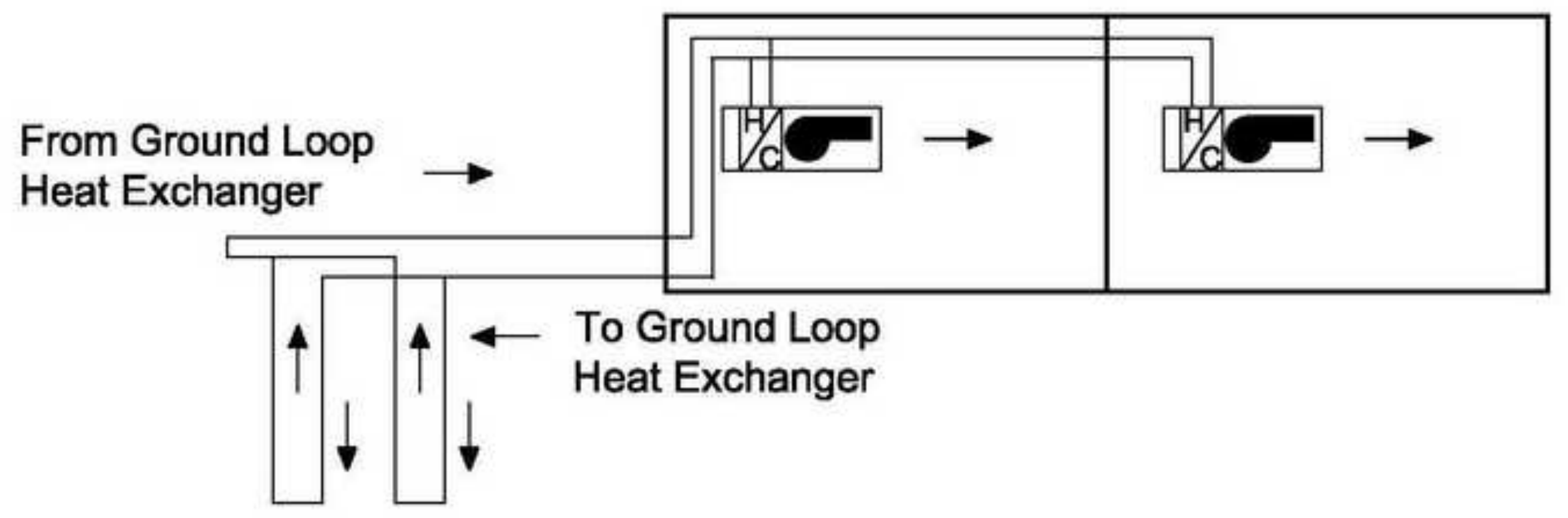

From Ground Loop 
A cooling tower and/or a boiler in series and downstream of GLHX

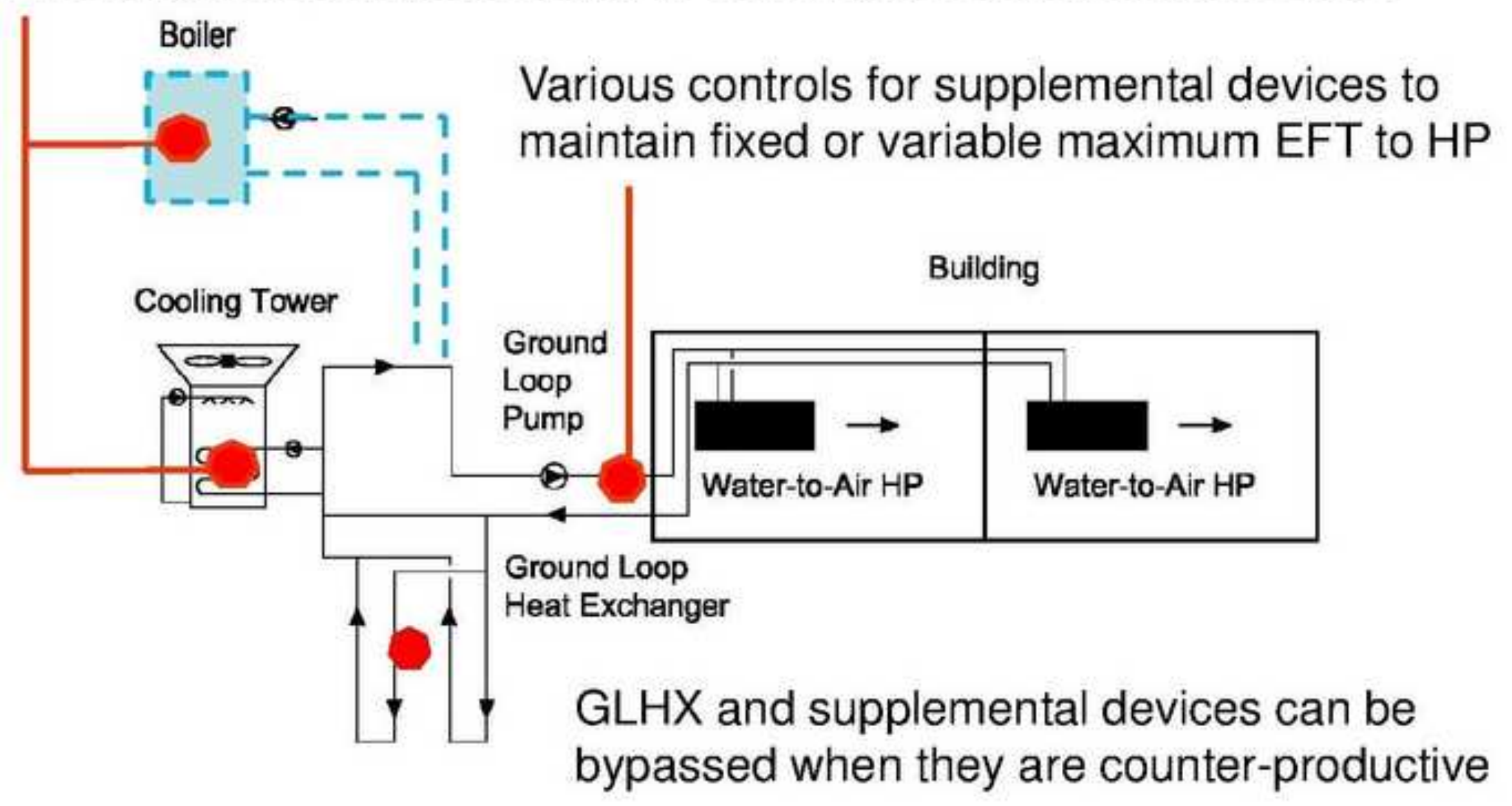



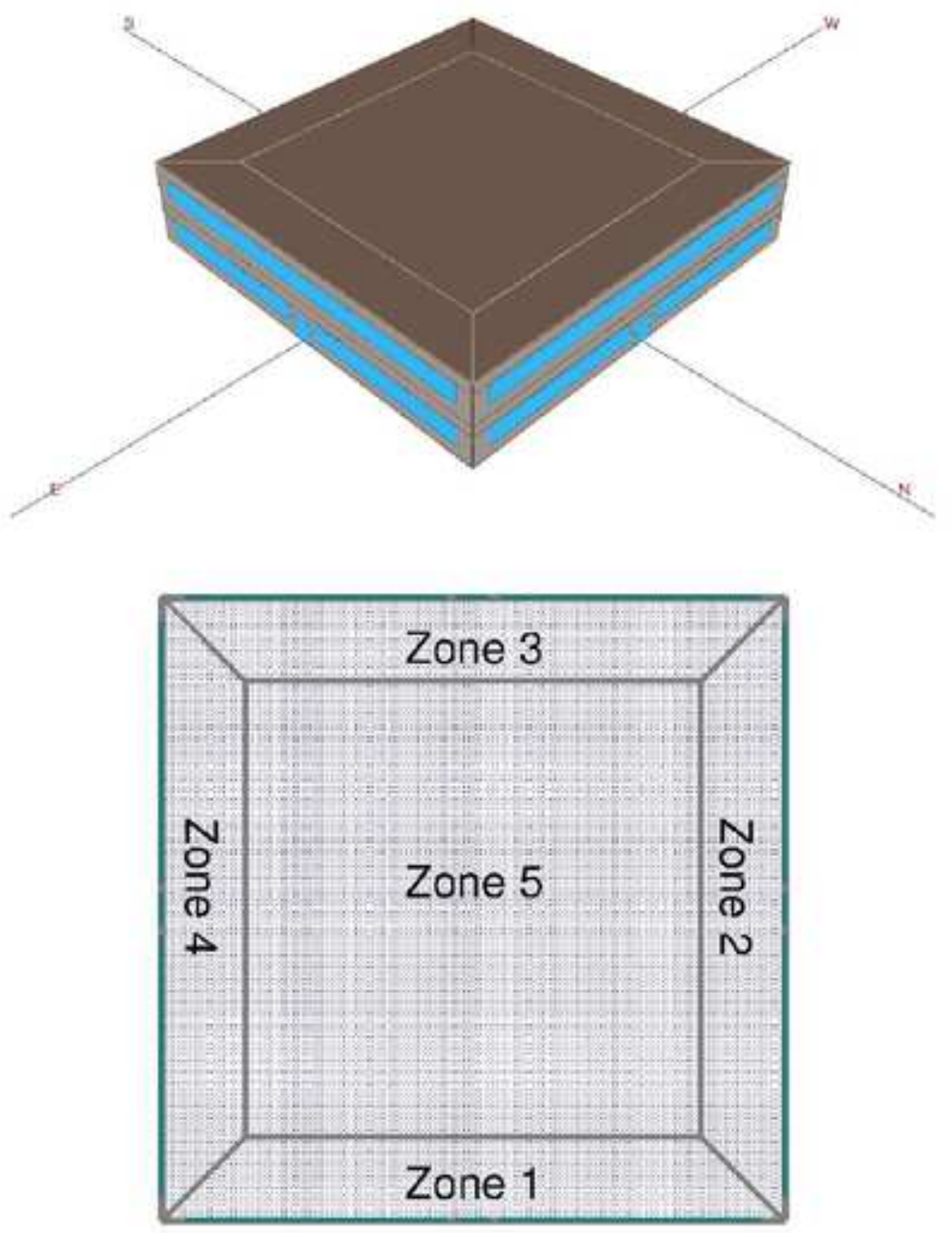

rage 35 of 42 
Figure(s)

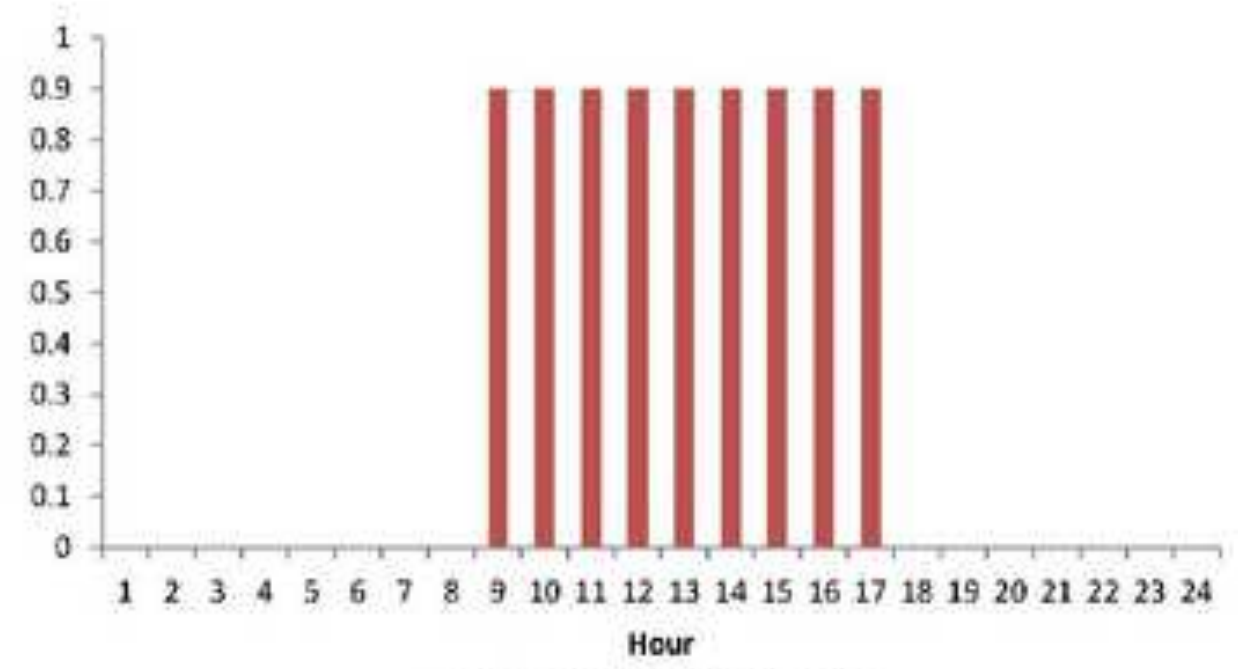

(a) Building octupancy schedule

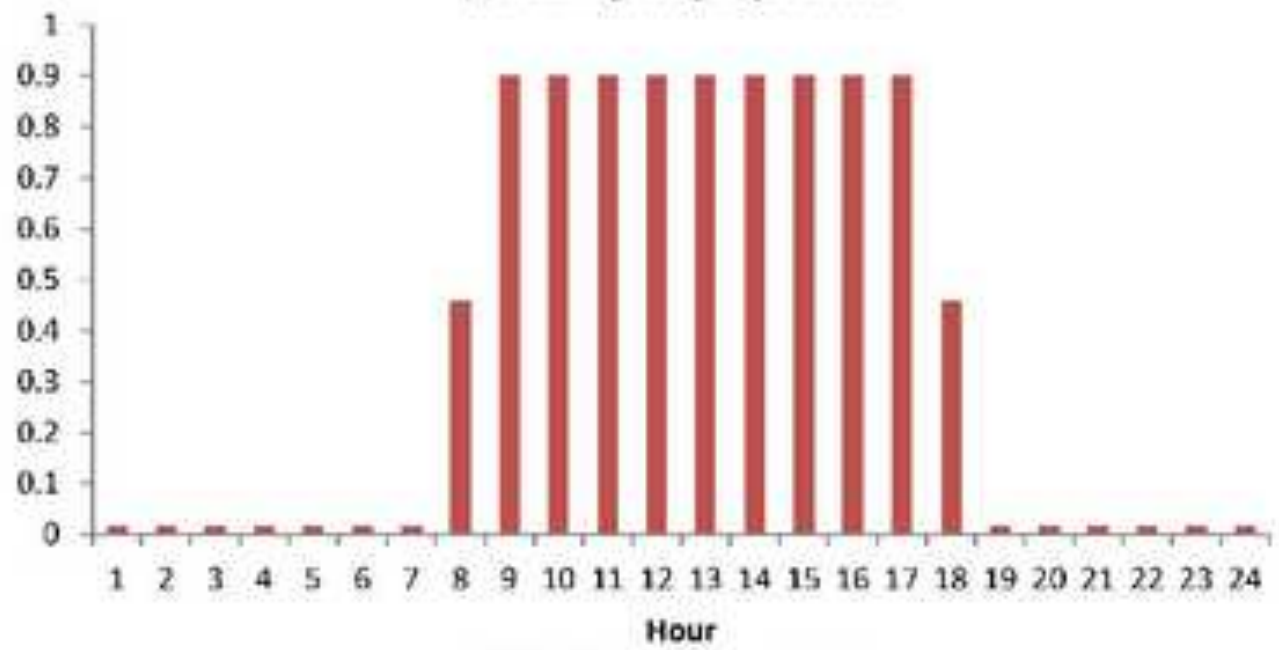

(b) Bailding lighting schedule

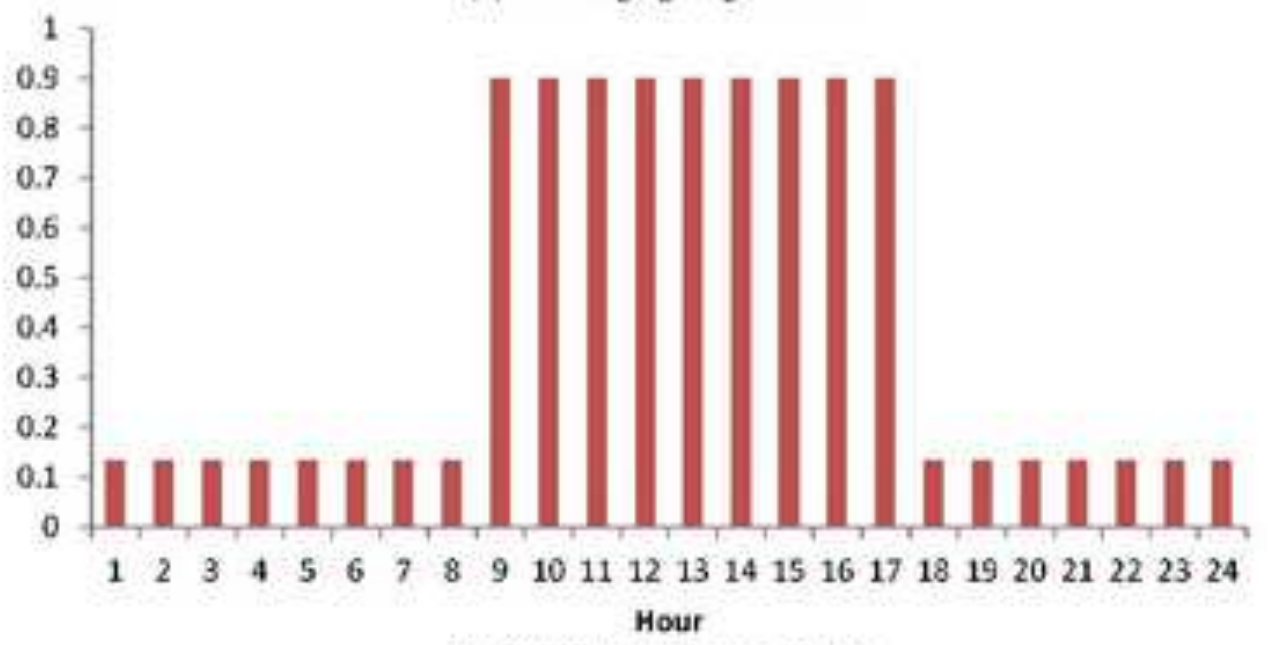

(c) Building equipment schedule 


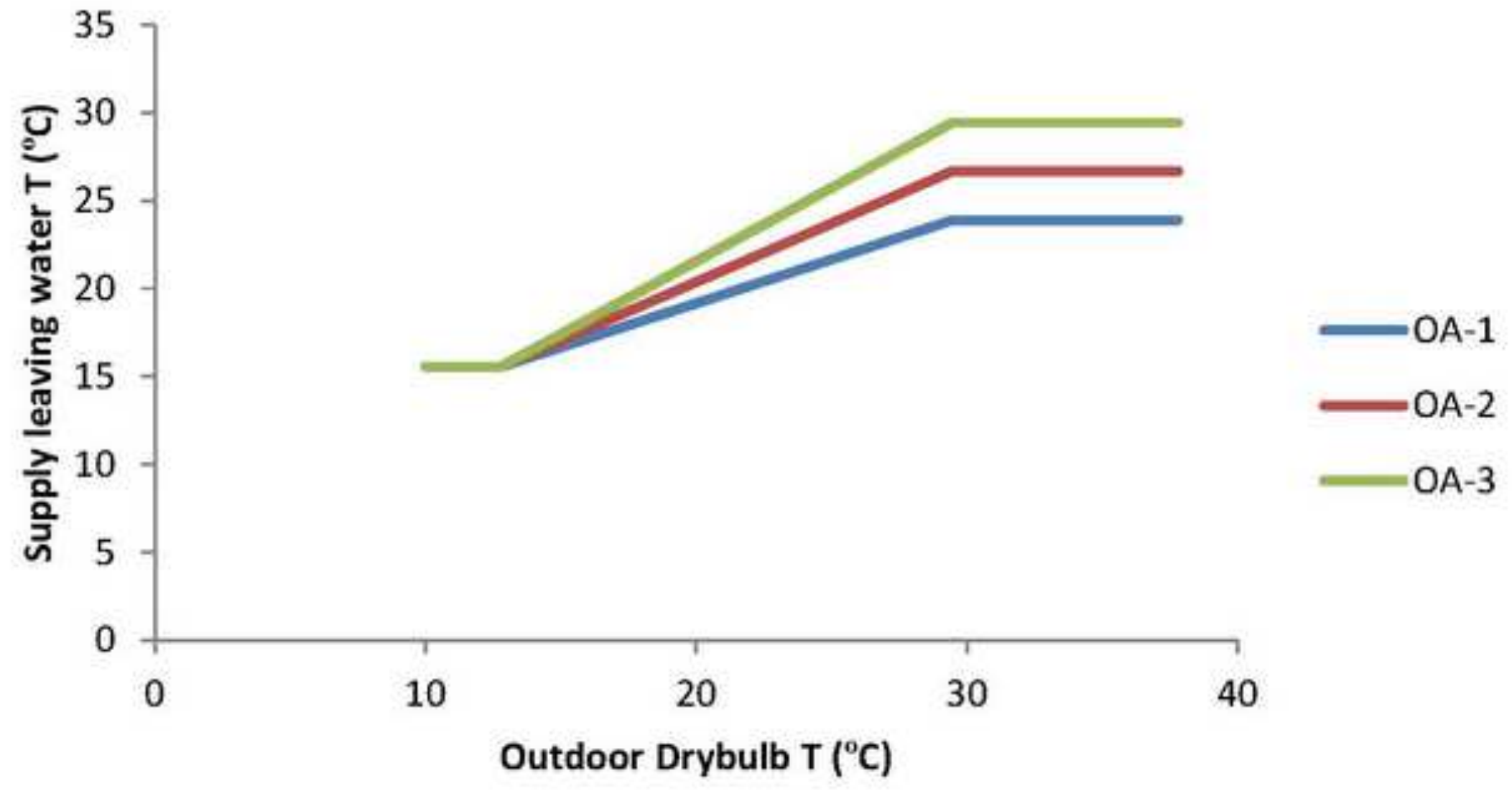




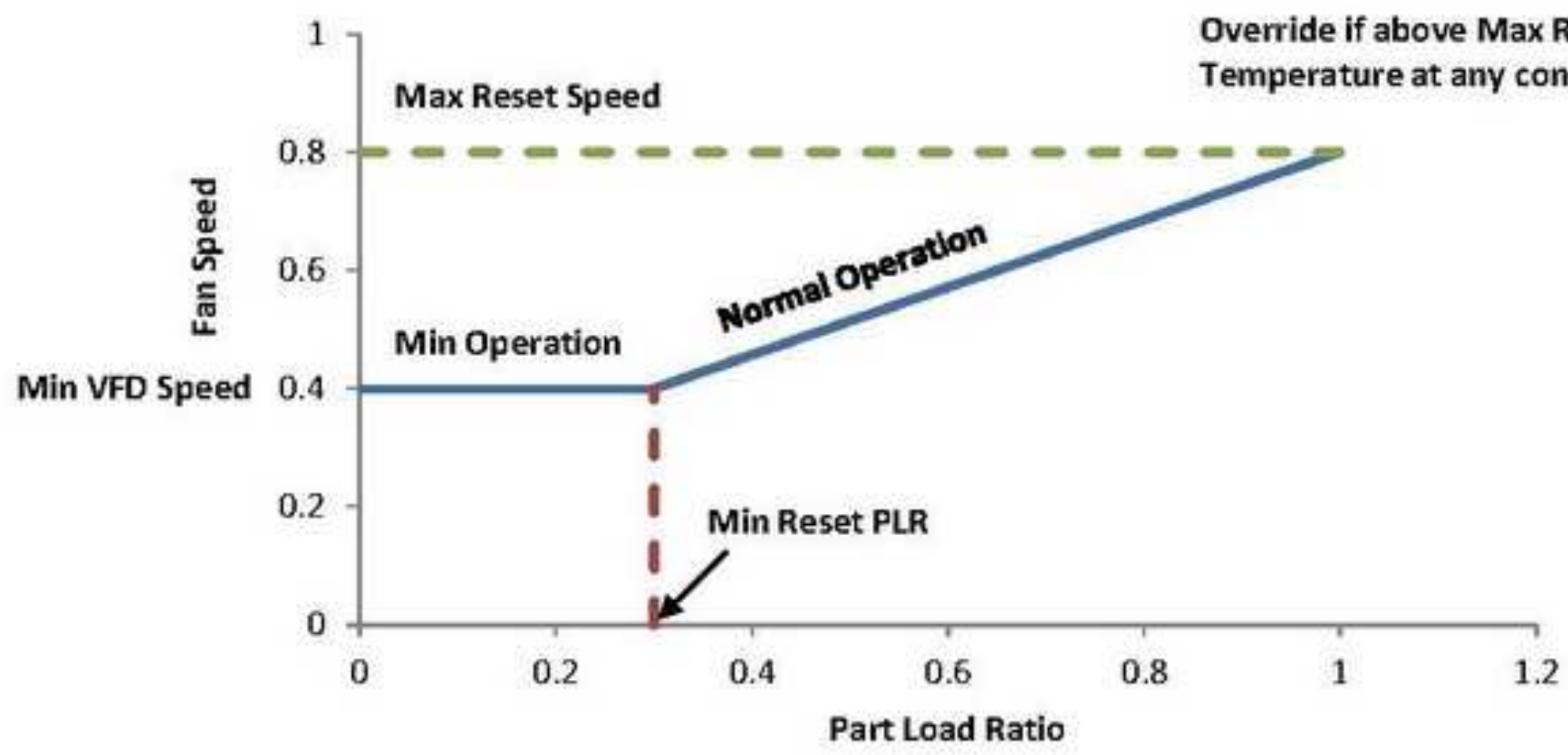

Override if above Max Reset

Temperature at any condition 


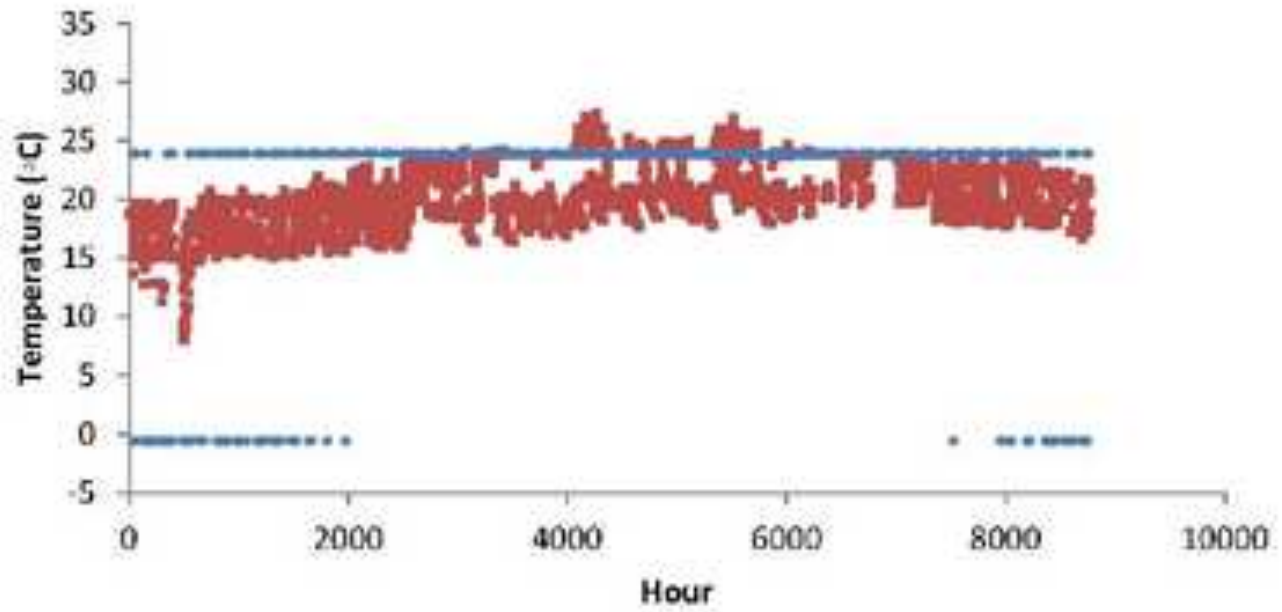

(a) Fixed-1

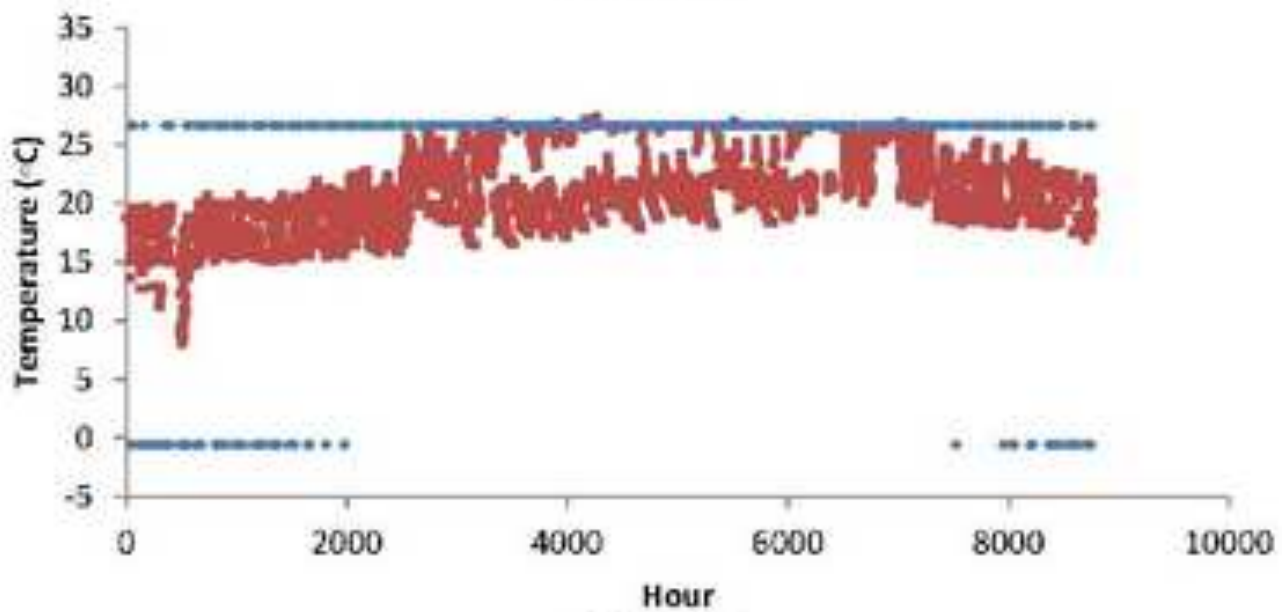

(b) Fixed-2

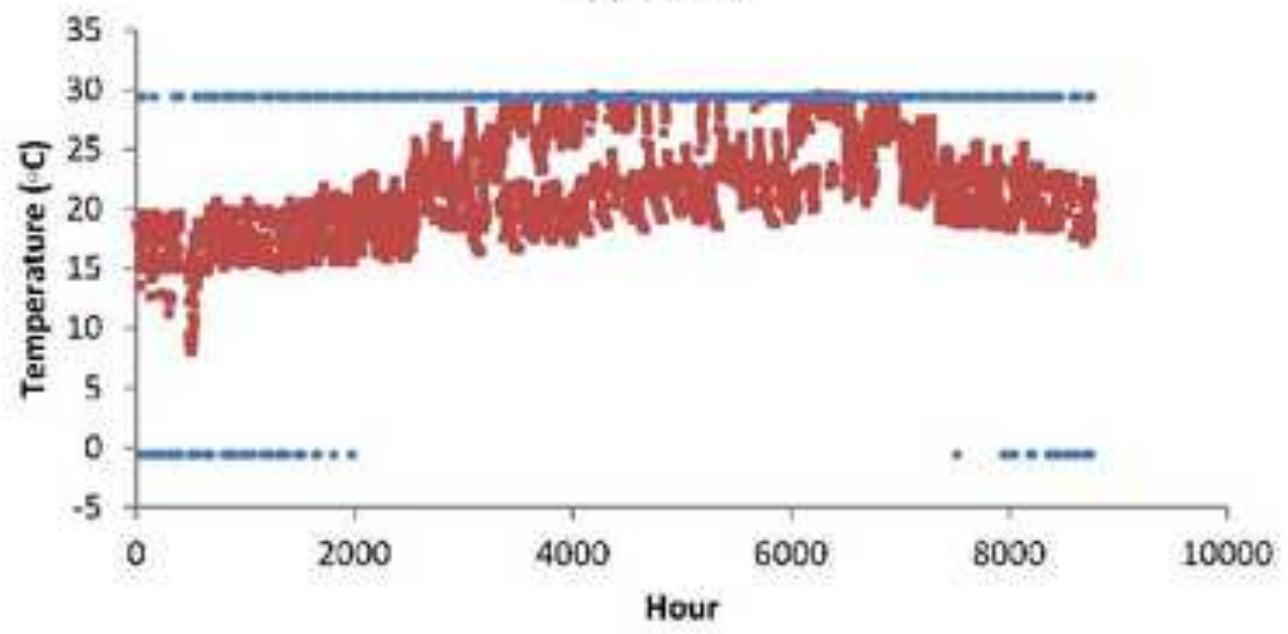

- EFT - Control setpoint T

(c) Fixed-3 


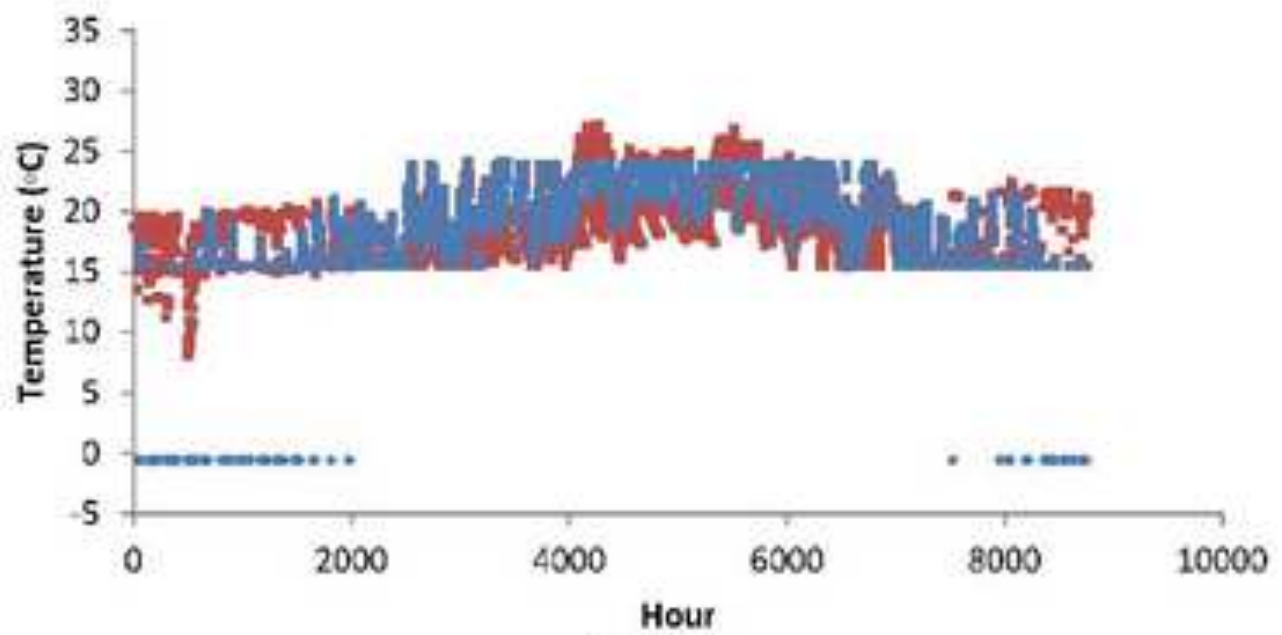

(a) $\mathrm{OA}-1$

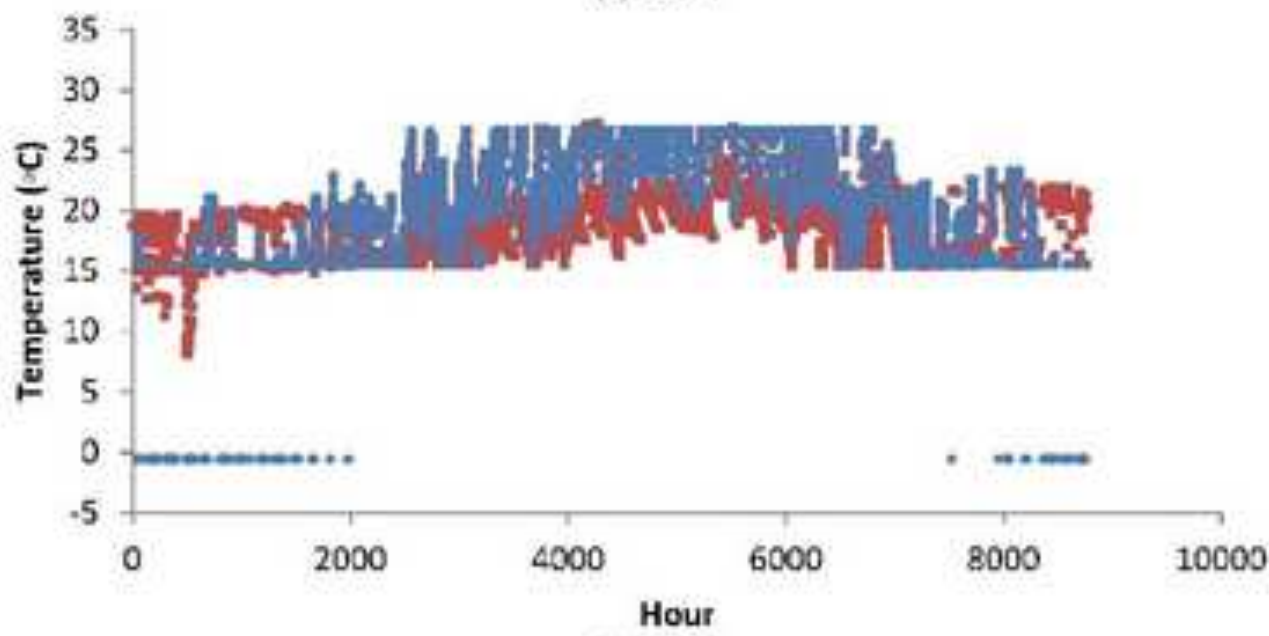

(b) $\mathrm{OA}-2$

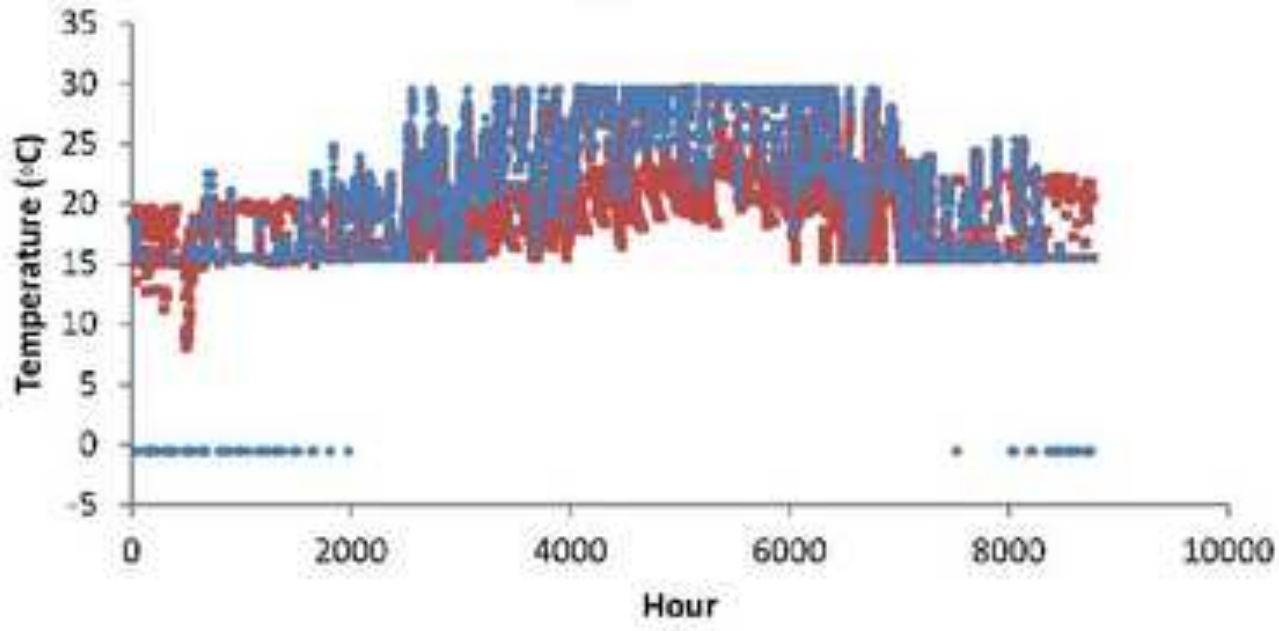

- EFT - Control setpoint T

(c) $0 \mathrm{~A} \cdot 3$ 


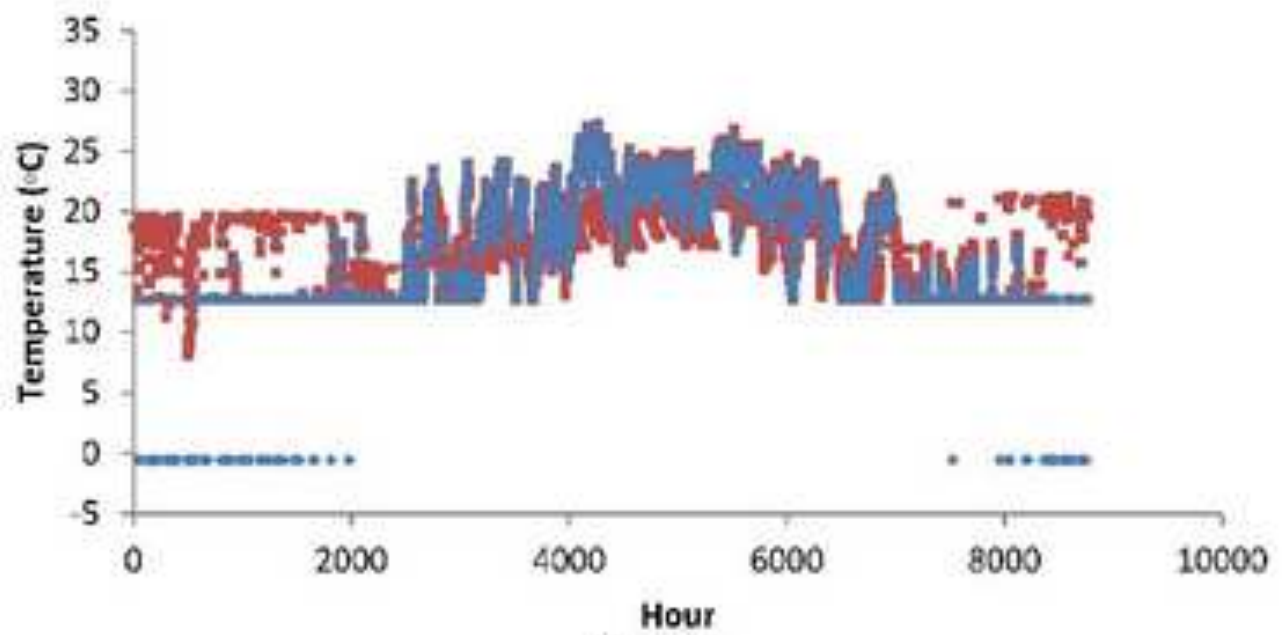

(a) WB-I

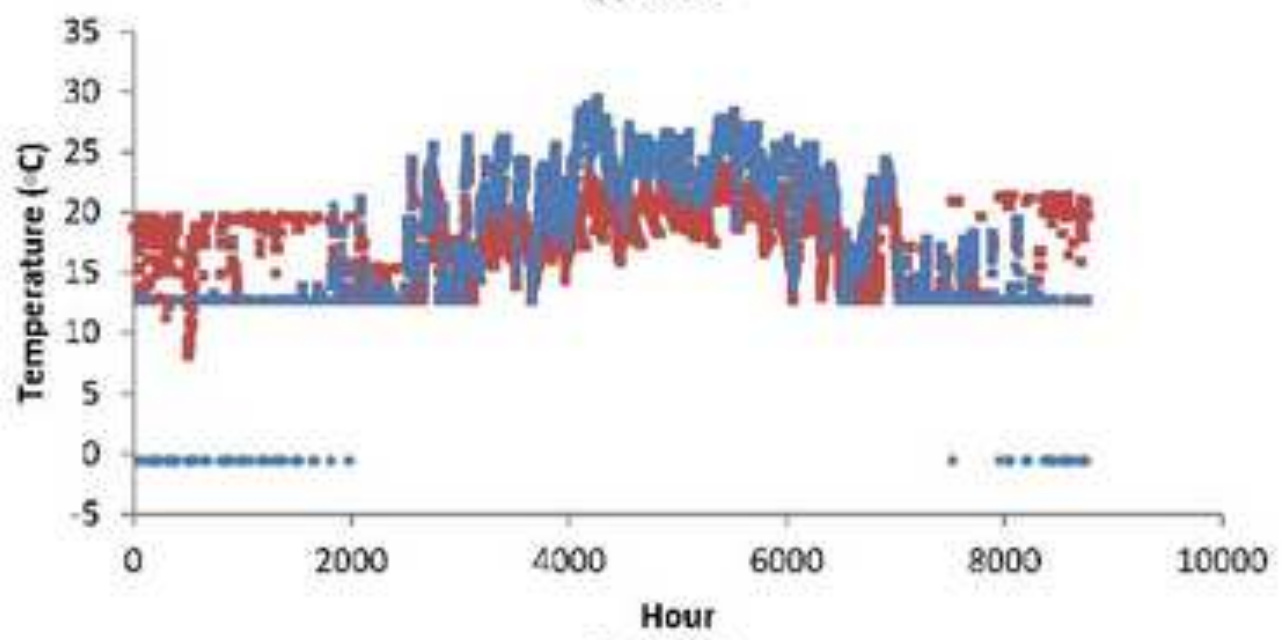

(b) WB-2

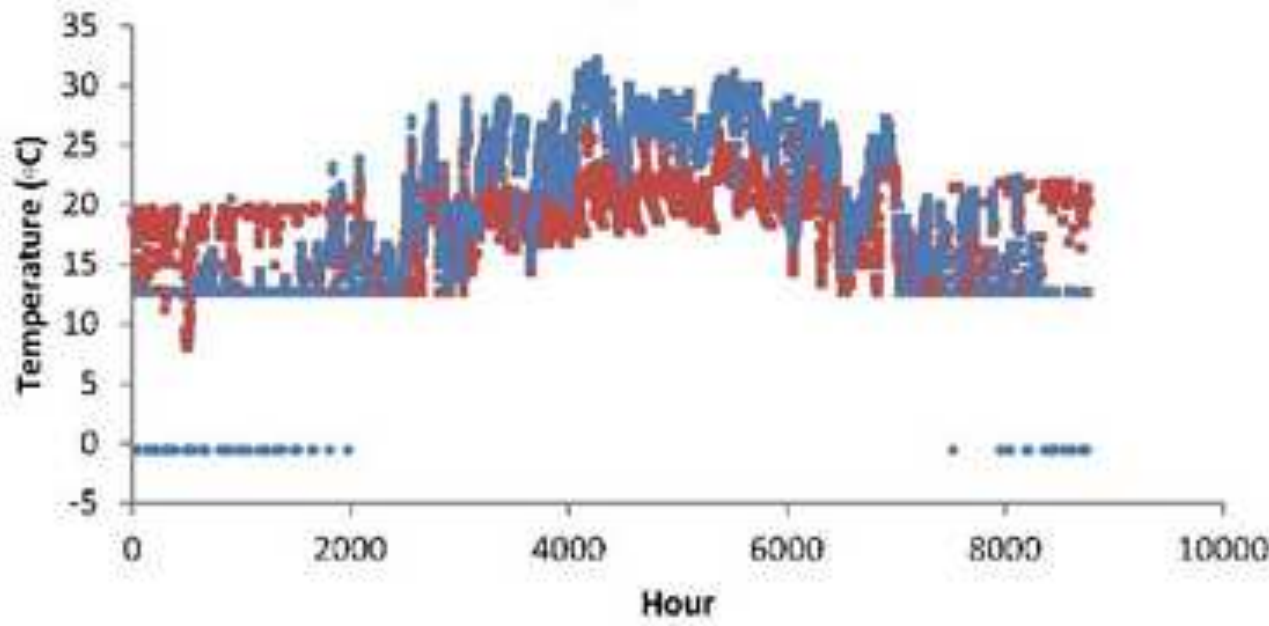

- EFT - Control setpoint T

(c) WB-3 


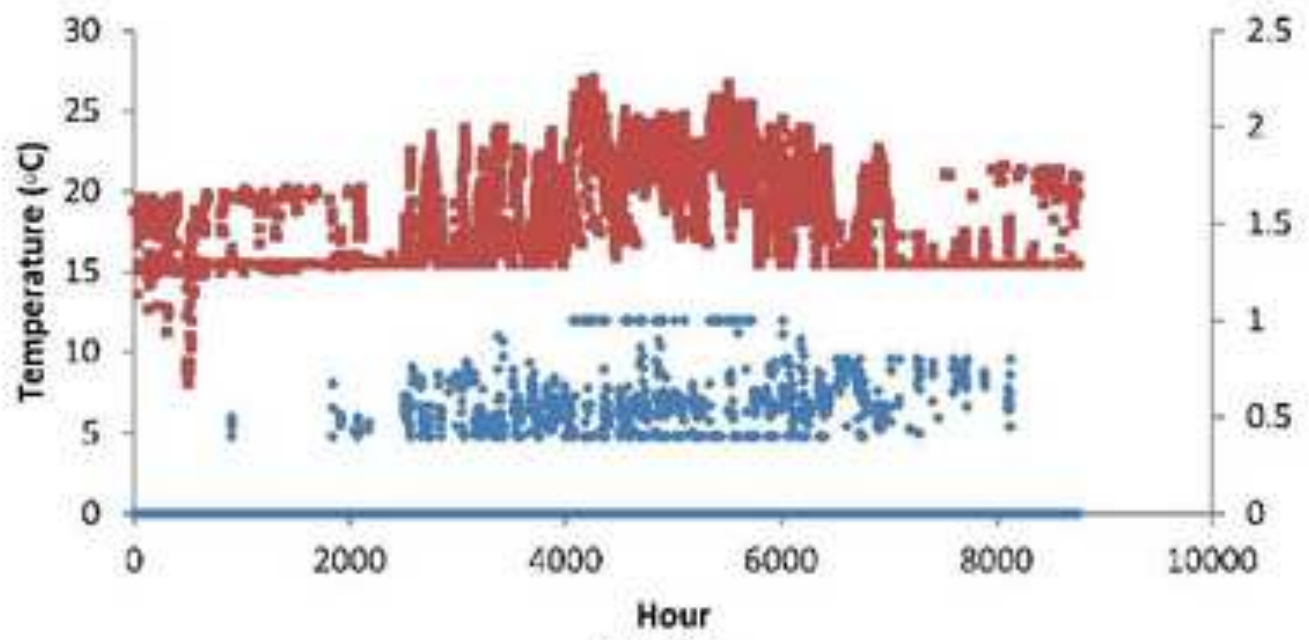

(a) LD-I

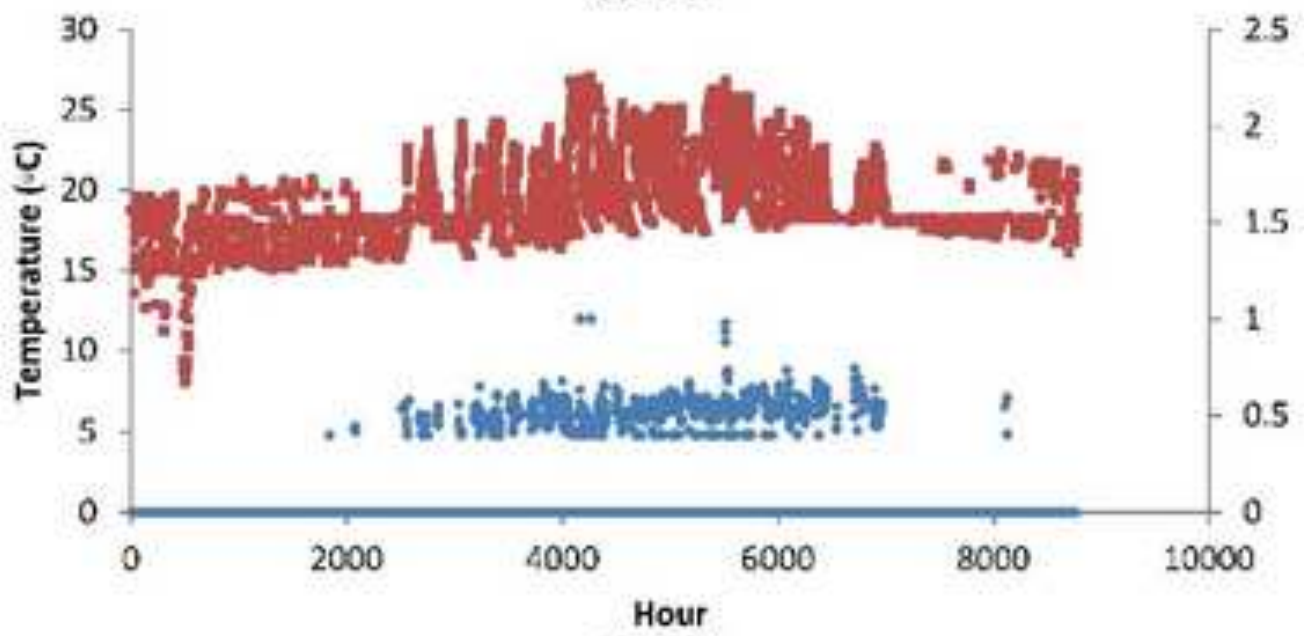

(b) LD.2

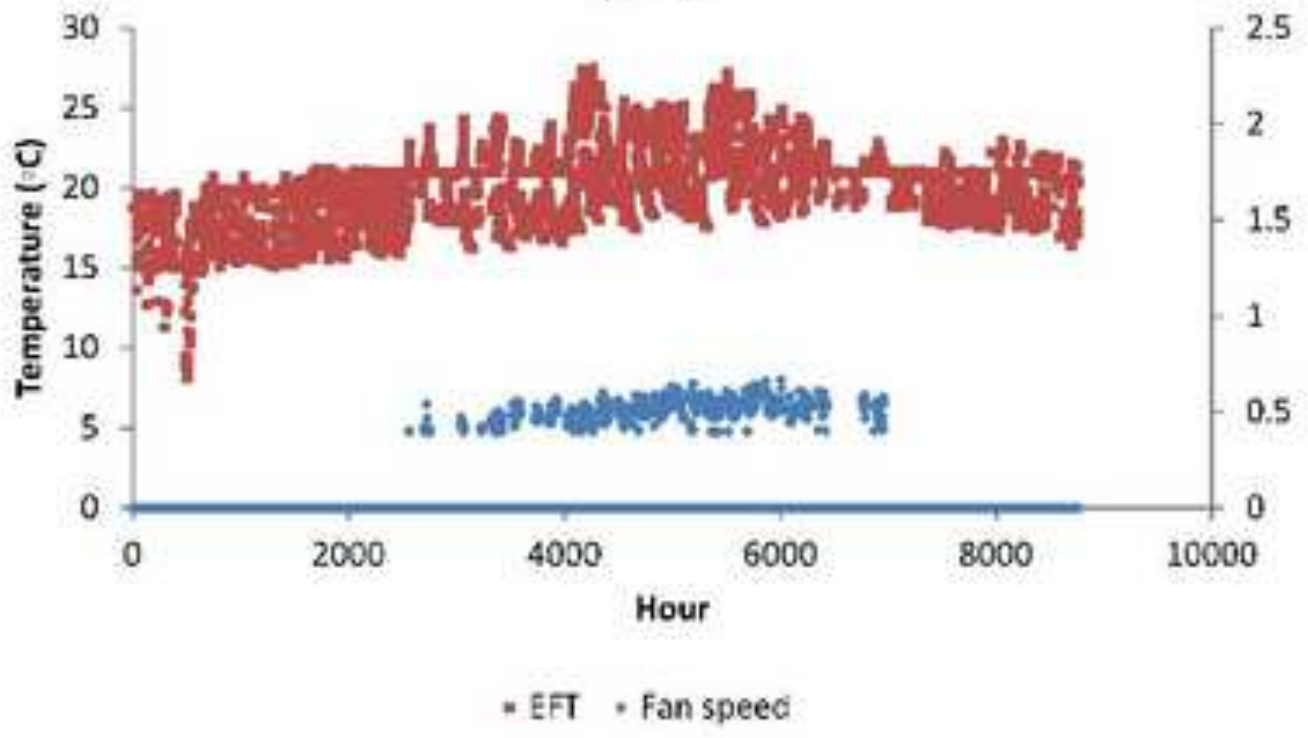

(c) LD-3 